\author{
Anna Knocińska \\ Wydziat Pedagogiki \\ Gnieźnieńska Szkoła Wyższa Milenium

\section{Tradycje zinstytucjonalizowanego poradnictwa psychologiczno-pedagogicznego w Wielkopolsce przed rokiem 1945}

\begin{abstract}
Anna Knocińska, Institutiolized traditions of psychological and pedagogical counseling in Great Poland before 1945

The main aim of the dissertation is to present the institutionalized traditions of psychological and pedagogical counseling in Great Poland before 1945. It brings closer the socio-political situation as well as the conditions resulting from the development of the social sciences that influenced the beginning of the first counseling institutions in Great Poland and in the whole country. It also shows the individual counseling posts that started functioning in Poznan in 1945. The outbreak of the World War II interrupted the development of psychological and pedagogical counseling in Great Poland.
\end{abstract}

Keywords: Counseling, Psychological And Pedagogical Counseling Service, The Interwar Period (1918-1939), Great Poland

Tworzenie instytucji poradnictwa w Wielkopolsce zainspirowane zostało, podobnie jak w całej Polsce, przez rozwój w obszarze nauk społecznych, a także splot czynników politycznych, ustrojowych, ekonomicznych, społecznych. Idee poradnictwa, zwłaszcza zawodowego, nabierały szczególnego znaczenia w kontekście światowego rozwoju przemysłowo-gospodarczego, pojawienia się nowych zawodów, a także potrzeby doboru odpowiednich pracowników na stanowiska pracy czy uczniów do szkolenia zawodowego. Na początku XX w. zaczęto więc organizować instytucje poradnictwa zawodowego. Najbardziej problematyka ta interesowała pracodawców, związki cechowe, związki zawodowe. Dopiero później w finansowanie poradni działających w powiązaniu z pośrednictwem pracy i szkolnictwem włączyły się instytucje państwowe.

Sytuacja Polski do roku 1914, czyli brak niepodległości i możliwości swobodnego rozwoju wszelkiego rodzaju polskich inicjatyw opóźniły początkowo rozwój instytucji poradnictwa. Do I wojny światowej rejon Wielkopolski był podzielony między dwóch 
zaborców według ustaleń Kongresu Wiedeńskiego z 1815 r. Wschodnie ziemie Wielkopolski z Kaliszem, Koninem, Słupcą, Turkiem i Kołem znajdowały się pod zaborem rosyjskim, w obrębie Królestwa Polskiego. Ziemie zachodnie od Prosny i Jez. Powidzkiego, czyli dawne województwa poznańskie, gnieźnieńskie i część kaliskiego przyłączono do Prus. Na obszarze zaboru pruskiego utworzono autonomiczne początkowo Wielkie Księstwo Poznańskie, do którego włączono na północy także okolice Bydgoszczy i Piły, a na południu część dawnego województwa sieradzkiego (okolice Ostrzeszowa i Kępna). Poza Księstwem znalazła się natomiast ziemia wałecka ${ }^{1}$. Po przegranych powstaniach zbrojnych na ziemiach polskich, od 1848 r. Wielkie Księstwo Poznańskie utraciło całkowicie autonomię, stało się prowincją poznańską z pruską administracją. Taki stan rzeczy utrzymał się aż do roku 1918.

Po odzyskaniu przez Polskę niepodległości, wytyczanie granic zewnętrznych odbywało się w toku sporów, przetargów dyplomatycznych i konfliktów zbrojnych niemal ze wszystkimi sąsiadami². Po niemieckiej stronie granicy pozostały południowo- i północno-zachodnie obrzeża dawnej Wielkopolski, z miastami: Wschową, Szlichtyngową, Babimostem, Pszczewem, Trzcielem, Międzyrzeczem, Bledzewem, Skwierzyną, Trzcianką, Piłą, Wałczem, Złotowem. Na terenach tych Niemcy utworzyli prowincję Grenzmark Posen-Westpreussen ze stolicą w Pile ${ }^{3}$. W Polsce natomiast dokonano wewnętrznego podziału administracyjnego zgodnie z przedrozbiorowymi tradycjami. Na obszarze Wielkopolski, z terenu dawnego Wielkiego Księstwa Poznańskiego utworzono województwo poznańskie. Obejmowało ono przez długi okres również Bydgoszcz i jej okolice po Strzelno, Szubin i Wyrzysk, przeniesione dopiero w roku 1938 do województwa pomorskiego. Wschodnia część regionu Wielkopolski (poprzedni zabór rosyjski) znalazły się w województwie łódzkim. Właśnie w 1938 r., gdy dokonywano w całej Polsce zmian administracyjnych, które miały zatrzeć różnice między obszarami byłych zaborów, do poznańskiego przyłączono powiaty: kolski, koniński, kaliski i turecki.

W okresie dwudziestolecia międzywojennego - pomimo trudności wynikających z okresu rozbiorów, zniszczeń wojennych czy wreszcie wielkiego kryzysu ekonomicznego - województwo poznańskie wyróżniało się na tle kraju. Dochód narodowy na jednego mieszkańca był wyższy niż w większości regionów Polski. Na wysokim poziomie stało zmechanizowane rolnictwo - dominująca w Wielkopolsce gałąź gospodarki. Na terenie województwa poznańskiego i pomorskiego znajdowało się łącznie ok. 40\% maszyn rolniczych z całego kraju. Wielkopolska dostarczała dwukrotnie wyższe zbiory zboża niż inne regiony. Pomyślnie rozwijała się hodowla, co wyrażało się np. eksportem masła, który stanowił $40 \%$ ogólnego eksportu tego produktu z kraju. W powiązaniu z rolnictwem rozwijał się przemysł rolno-spożywczy. Na terenie Wielkopolski znajdowało się około połowy wszystkich prywatnych cukrowni w Polsce, a także najważniejsze zakłady przemysłu krochmalniczego i suszarniczego. Na wysokim poziomie stał przemysł drzewny, z głównym ośrodkiem w Poznaniu. Tam też funkcjonował jedyny duży zakład prze-

1 J. Topolski, Wielkopolska poprzez wieki, Poznań 1999, s. 165.

2 Por. Cz. Brzoza, A. L. Sowa, Historia Polski 1918-1945, Kraków 2006.

3 J. Topolski, op. cit., s. 252. 
mysłowy - Fabryka Hipolita Cegielskiego oraz koncentrowały się mniejsze zakłady przemysłowe. Wielkopolska znajdowała się również na trzecim miejscu w kraju pod względem liczby zakładów rzemieślniczych. Ponadto dzięki gęstej sieci kolejowej z okresu zaboru pruskiego województwo poznańskie miało najlepiej działający transport i związany z nim handel. Zatrudnienie w handlu znajdowała tam najwyższa w skali kraju liczba ludności. Rozwój regionu wzbogaciła m.in. organizacja w latach 20. Targów Poznańskich, które szybko zyskały wymiar międzynarodowy.

Poznań był niewątpliwie głównym ośrodkiem regionu pod względem gospodarczym, ale również kulturalnym i naukowym. Właśnie tam zakładano: szkoły wyższe, teatry, muzea, biblioteki, rozgłośnie naukowe, koncerny prasowe ${ }^{4}$. Istotnym wydarzeniem dla rozwoju życia kulturalnego i naukowego w Wielkopolsce, ale także dla rozkwitu polskiej nauki było utworzenie w 1919 r. Wszechnicy Piastowskiej w Poznaniu ${ }^{5}$, przemianowanej wkrótce na Uniwersytet Poznański. Pierwszym rektorem został wybrany prof. Heliodor Święcicki. Natomiast pierwszą funkcjonującą jednostką uniwersytecką był wielokierunkowy Wydział Filozoficzny. W jego skład wchodziło m.in. Studium Psychologii, nazywane w okresie II Rzeczypospolitej również Zakładem Psychologicznym, Instytutem Psychologicznym, Katedrą Psychologii. Do jej organizacji i kierowania powołano dr. Stefana Błachowskiego, rekomendowanego przez prof. Kazimierza Twardowskiego z Uniwersytetu Jana Kazimierza we Lwowie. Tego samego roku S. Błachowski, po habilitacji, otrzymał w Poznaniu stanowisko profesora nadzwyczajnego psychologii i pedagogiki eksperymentalnej (dwa lata później został profesorem zwyczajnym).

Prof. S. Błachowski kierował Katedrą Psychologii od jej założenia do wybuchu II wojny światowej. W ramach zajęć akademickich prowadził wykłady i ćwiczenia z zakresu psychologii, obejmujące m.in. następujące tematy: metody, wrażenia, wyobrażenia, myślenie, uczucia, wola, psychologia pamięci ze szczególnym uwzględnieniem pedagogiki eksperymentalnej, główne problemy pedagogiki eksperymentalnej, psychologia eksperymentalna, psychologia pracy umysłowej, a także ćwiczenia psychologiczne dla początkujących w Pracowni psychologii eksperymentalnej ${ }^{6}$. Interesował się także psychologią sportu i psychologią sztuki. W pracy naukowo-badawczej podejmował głównie zagadnienia psychologii rozwojowej i wychowawczej. Problematykę wychowawczą ściśle wiązał z poradnictwem zawodowym i selekcją szkolną. Pomagał w zakładaniu placówek psychologii stosowanej w Poznaniu i na Śląsku. Jego działalność przyczyniła się do rozwoju polskiej psychotechniki w okresie II Rzeczypospolitej. Był uczestnikiem wielu krajowych i zagranicznych konferencji psychotechnicznych; reprezentował Polskę w Komitecie Dyrektorów Międzynarodowych Konferencji Psychotechnicznych; współredagował kwartalnik „Psychotechnika” oraz czasopisma zagraniczne „The Psychological Register”, „Character and Personalisty”, „Psychological Abstracts”;

\footnotetext{
${ }^{4}$ Por. Cz. Brzoza, A. L. Sowa, op. cit., s. 371.

5 Por. Otwarcie Wszechnicy Piastowskiej w Poznaniu, „Kurier Poznański” 1919.05.10 R.14 nr 107, s. 1-2; Otwarcie Wszechnicy w Poznaniu, „Dziennik Poznański” 1919.05.08 R.61 nr 106, s. 1.

${ }^{6}$ Por. Stefan Błachowski. Założyciel poznańskiej psychologii, Seria Klasycy Nauki Poznańskiej, Tom 31, wstęp i wybór tekstów R. T. Stachowski, Poznań 2009.
} 
czynnie działał w Polskim Towarzystwie Psychotechnicznym; był w zarządzie Poznańskiego Towarzystwa Filozoficznego. W 1929 r. założył Poznańskie Towarzystwo Psychologiczne, a rok później zaczął wydawać „Kwartalnik Psychologiczny”. W swojej aktywności zawodowej dążył do możliwie najbliższego powiązania psychologii z życiem, teorii z praktyką. Postulował szerokie zastosowanie psychologii w wychowaniu, lecznictwie, sądownictwie, przemyśle, komunikacji, sporcie i sztuce ${ }^{7}$.

Działalność prof. S. Błachowskiego, a w szerszym kontekście powstanie i rozwój poznańskiej Katedry Psychologii oraz wspomniana wcześniej koncentracja w Poznaniu wielkopolskiego przemysłu i licznych zakładów rzemieślniczych sprawiły, że Poznań stał się także ośrodkiem poradnictwa psychologiczno-pedagogicznego na terenie Wielkopolski.

Wzmianki na temat zakładania instytucji poradnictwa w Poznaniu sięgają co prawda okresu przed I wojną światową, brak jednak bliższych danych na ten temat. J. Włodek-Chronowska wymienia poradnię zawodową przy Miejskim Biurze Pośrednictwa Pracy w Poznaniu jako pierwszą tego typu placówkę na ziemiach polskich ${ }^{8}$. W okresie II Rzeczypospolitej funkcjonowało w Poznaniu już kilka poradni, co lokowało Wielkopolskę wśród najbardziej rozwiniętych pod tym względem regionów. Najwięcej placówek poradnictwa powstało w Warszawie, nieco mniej w Lodzi, Lwowie, Krakowie, Katowicach i właśnie w Poznaniu.

Pierwszą na terenie Wielkopolski poradnię zawodową po I wojnie światowej założył z dniem 1 września 1925 r. Związek Towarzystw Przemysłowych i Rzemieślniczych w Poznaniu9. Placówka pod nazwą Porada Zawodowa (Gabinet Psychotechniczny) dla Rzemiosła i Przemysłu, z siedzibą przy Placu Sapieżyńskim nr 9, stanowiła jeden z działów związku i funkcjonowała w oparciu o jego statut. Jej otwarcia dokonano przy wsparciu S. Dybczyńskiego, naczelnika Wydziału Szkół Zawodowych w Kuratorium Okręgu Szkolnego Poznańskiego, ale finansowana była w całości przez związek. Badania prowadzone były odpłatnie, a za pozyskane w ten sposób fundusze dokonywano zakupu niezbędnych druków: kwestionariuszy, testów, skali itp. Aparaturę natomiast wykonywali w większości nieodpłatnie poznańscy rzemieślnicy. Dwa lata po założeniu poradnia posiadała na wyposażeniu 197 przyrządów psychotechnicznych w 21 rodzajach. Czyniono jednak starania w Magistracie Miasta Poznania o subwencję na zakup bardziej skomplikowanych i precyzyjnych urządzeń zagranicznych, np. dynamomierz, ergograf, impulsomierz, optomierz z mikroskopem, tremomierz, tachistoskop, aparat rotacyjny barw, poligraf, spiromierz, chronometr.

Jak twierdziły władze związku, była to wtedy jedyna tego typu instytucja w zachodniej Polsce, dlatego jej działalność uznawano za najważniejsze zadanie związku wobec

7 J. Budkiewicz, J. Kączkowska, Z dziejów psychologii stosowanej w Polsce do roku 1957 ze szczególnym uwzględnieniem poradnictwa zawodowego, Warszawa 1987, s. 249-252.

8 J. Włodek-Chronowska, Poradnia wychowawczo-zawodowa w systemie orientacji zawodowej, Warszawa 1980, s. 10; J. Włodek-Chronowska odwołuje się do informacji J. Dreckiego w: Poradnictwo w zakresie wyboru zawodu, red. W. Hauszyld, Warszawa 1926.

${ }^{9}$ Pismo Związku Towarzystw Przemysłowych i Rzemieślniczych w Poznaniu z dn. 22.03.1927 r. do Magistratu st. m. Poznania w sprawie subwencji na gabinet psychotechniczny, Archiwum Państwowe w Poznaniu (APP), Akta Miasta Poznania, sygn. 3320. 
rzemiosła i drobnego przemysłu. Podkreślano również znaczenie poradnictwa zawodowego w wymiarze indywidualnym, jako warunkujące szczęście i powodzenie w życiu. Celem Porady Zawodowej było więc z jednej strony poradnictwo zawodowe dla uczniów oparte na badaniach psychotechnicznych ich zdolności fizycznych i umysłowych, a z drugiej - badanie rynku pracy i odpowiedni dobór zawodowy pracowników.

W obszarze poradnictwa zawodowego funkcjonowała również, założona w 1928 r. Poradnia Zawodowa dla Dziewcząt Stowarzyszenia „Służba Obywatelska” z siedzibą przy ul. Bukowskiej 1. Jej działalność nastawiona była jednak na poradnictwo zawodowe, preorientację zawodową i poradnictwo szkolne skierowane do dziewcząt. Prowadzono w niej selekcję tylko do żeńskich szkół zawodowych. Poradnia działała dzięki subwencji MWRiOP ${ }^{10}$. Podczas otwarcia lokalu poradni w roku 1930 obecni byli liczni goście związani właśnie z resortem oświaty: kurator poznańskiego okręgu szkolnego dr Joachim Namysł, były kurator Bernard Chrzanowski, naczelnik wydziału szkół handlowych i gospodarczych departamentu szkolnictwa zawodowego Ministerstwa Wyznań Religijnych i Oświecenia Publicznego Maria Zaborowska, wizytator szkół zawodowych żeńskich Madurowiczówna, a także kierowniczka centrali poradni zawodowych dla dziewcząt w Warszawie Janina Kączkowska ${ }^{11}$. Kierownikiem poradni była psycholog Helena Dachówna (później dr Helena Bilińska), wymieniana wśród pionierów polskiej psychologii stosowanej, prowadząca żywą działalność w zakresie preorientacji zawodowej w Poznaniu i województwie ${ }^{12}$.

W województwie poznańskim, podobnie jak w całej Polsce, rozwijał się nie tylko zawodowy nurt poradnictwa. Starania o utworzenie poradni na wzór wychowawczo-leczniczych podjął na początku roku 1928 kierownik szkoły specjalnej w Poznaniu - pan Kuhn. Proponował objęcie opieką dzieci upośledzonych umysłowo i fizycznie, z wadami wzroku, słuchu i wymowy oraz dzieci moralnie zaniedbane. Głównym zadaniem poradni miała być jednak selekcja dzieci i młodzieży do szkolnictwa specjalnego. Kadrę poradni mieli stanowić: psycholog, pedagog i lekarz ${ }^{13}$. Początkowo Inspektorat Szkolny w Poznaniu ustosunkował się negatywnie do tej propozycji, proponowano porozumienie z funkcjonującą już w Poznaniu poradnią i dostosowanie profilu jej działalności do potrzeb szkolnictwa specjalnego. Plany te konsultowano z kierownikiem Instytutu Psychologii Uniwersytetu Poznańskiego, prof. S. Błachowskim. Uzgadniano z nim także ewentualne zatrudnienie pracowników i wyposażenie gabinetu psychologicznego, o którego organizacji podjęto decyzję pod koniec roku 1929.

W ten sposób powstało Miejskie Laboratorium Psychologiczne z siedzibą przy ul. Wielkie Garbary 26. Jego podstawowym zadaniem była selekcja dzieci do szkolnictwa specjalnego, a z czasem rozszerzono działalność również o poradnictwo zawodowe. Głównym organizatorem, kierownikiem, a początkowo również jedynym pracownikiem,

\footnotetext{
10 J. Budkiewicz, J. Kączkowska, op. cit., s. 71.

${ }^{11}$ Opis zdjęcia z otwarcia poradni w Poznaniu, Narodowe Archiwum Cyfrowe, Koncern Ilustrowany Kurier Codzienny - Archiwum Ilustracji, sygn. 1-P-426.

12 J. Budkiewicz, J. Kączkowska, op. cit., s. 255.

13 Pismo Kierownika szkoły specjalnej z dn. 24.01.1928 r. do Inspektoratu Szkolnego w Poznaniu w sprawie utworzenia poradni wychowawczo-leczniczej, APP, Akta Miasta Poznania, sygn. 3321, s. 4-5.
} 
był Jan Lewandowicz, nauczyciel szkoły specjalnej. W pracy stosował kwestionariusze selekcyjne i indywidualne, protokoły i informacje z badań własnego autorstwa. Podstawowym narzędziem badawczym był test Bineta-Simona w przeróbce Termana. J. Lewandowicz dbał o wyposażenie placówki w testy, literaturę, przyrządy, m.in. estezjometr, tachistoskop, ergograf, metronom. Po roku samodzielnej pracy, w związku z dużym zapotrzebowaniem na badania, bezpłatnej pomocy udzielał mu inny nauczyciel szkoły specjalnej - Tadeusz Susło, a jeszcze później pan Roszczak. W 1932 r., z powodu wyjazdu J. Lewandowicza na roczny kurs nauczycielski do Torunia, powierzono zastępstwo w laboratorium dr. Janowi Szwarcowi. Funkcję kierownika pełnił do końca 1934 r., natomiast z początkiem 1935 r. kierownictwo objął dr Jan Głaza, rekomendowany przez prof. S. Błachowskiego. W między czasie przeorganizowano placówkę na Miejską Pracownię Pedologiczną z siedzibą przy ul. Marii Magdaleny. Brak jednak precyzyjnych danych dotyczących tej zmiany ${ }^{14}$.

Kolejną placówkę poradnictwa w Poznaniu zorganizowano w 1932 r. W ramach Wojewódzkiego Instytutu Rzemieślniczo-Przemysłowego utworzono Poradnię Zawodową i Gabinet Psychotechniczny z siedzibą przy ul. Wały Zygmunta Augusta $15^{15}$. Przed nową instytucją postawiono zadania poradnictwa zawodowego dla kandydatów do rzemiosła i przemysłu oraz selekcji do szkół zawodowych. Zakres zadań poszerzono dodatkowo o pracę naukową. Wśród pracowników znaleźli się: Jan Schwarz, Stefan Frycz, A. Sroka, Adam Wegner. Publikacje z działalności zamieszczały uznane pisma fachowe („Psychotechnika”, „Polskie Archiwum Psychologii”, „Kwartalnik Psychologiczny”), czasopisma nauczycielskie („Nasz Głos”, „Głos Nauczycielski”, „Szkoła Śląska”), gazety codzienne („Kurier Poznański”, „Dziennik Poznański”, „Nowy Kurier”, „Gazeta Polska”) ${ }^{16}$. W latach 1934-1935 przygotowano również dwa tomy własnego wydawnictwa pod nazwą „Psychometrja”. Jego redaktorem naczelnym był kierownik poradni dr Jan Schwarz. Zamieszczone przez niego artykuły obrazowały zakres prowadzonych w placówce badań. Dotyczyły zagadnień ilorazu inteligencji, jego związku z płcią, wyników młodzieży poznańskich szkół; życzeń zawodowych młodzieży i związku zawodu z uzdolnieniami; problemu niepowodzeń szkolnych i oceniania w szkole; a także metod badawczych w poradnictwie ${ }^{17}$.

W wykazie placówek opieki psychologicznej nad dziećmi i młodzieżą funkcjonujących w okresie międzywojennym znalazły się jeszcze dwie poradnie z Poznania ${ }^{18}$. Jedna to Prywatna Poradnia Zawodowa „Psychotechnika”, oferująca badania psychotechniczne

${ }^{14}$ Informacje z nagłówków, pieczątek, adnotacji w różnych dokumentach, APP, Akta Miasta Poznania, sygn. 3321, s. 110, 158, 159, 162.

15 J. Budkiewicz, J. Kączkowska, op. cit., s. 71.

${ }^{16}$ Sprawozdanie Poradni Zawodowej i Gabinetu Psychotechnicznego Instytutu Rzemieślniczo-Przemysłowego w Poznaniu za okres 1 XI 1932 r. do 1 VII 1934 r., APP, Akta Miasta Poznania, sygn. 3321, s. $169-172$.

${ }_{17}$ Przeglad czasopism. Psychometrja I (1934) 1-2, 3-4, „Kwartalnik Psychologiczny” 1935, t. 6, s. 160-161 i $440-441$.

18 Por. D. Głuska, L. Goryński, Wykaz zakładów specjalnych dla dzieci i młodzieży. Spis poradni pedologicznych, psychologicznych $i$ zawodowych, Warszawa 1938. Załącznik do Biuletynu Instytutu Higieny Psychicznej 1938, nr 2. 
dla młodzieży. Jej siedziba znajdowała się przy ul. Bukowskiej 1. Druga to Poradnia Zawodowa Niemiecka „Berufshilfe”, prowadząca badania psychotechniczne, ale zajmująca się wyłącznie młodzieżą niemiecką. Usytuowana była w siedzibie przy ul. Piłsudskiego 27.

Prężny rozwój poradnictwa w Poznaniu, podobnie jak w całej Polsce, przerwał wybuch II wojny światowej. Teren Wielkopolski wraz ze znaczną częścią ziem polskich, będących pod okupacją niemiecką, włączono do III Rzeszy. Podjęto też natychmiastowe działania germanizacyjne - od wprowadzenia niemieckiej administracji, przez likwidację polskich instytucji, zakładów przemysłowych, warsztatów rzemieślniczych, sklepów, konfiskatę majątków ziemskich, aż do brutalnych wysiedleń i masowych egzekucji. Zlikwidowano więc również wszystkie związki zawodowe, towarzystwa, stowarzyszenia oraz polskie instytucje kulturalne i oświatowe, w tym szkoły, biblioteki, muzea, archi$\mathrm{wa}^{19}$.

Zamknięto Uniwersytet Poznański, a wraz z nim Instytut Psychologii. Większość wyposażenia Instytutu: aparatura do badań, pomoce naukowe i dydaktyczne uległy zniszczeniu w pożarze. Kierownika Instytutu prof. S. Błachowskiego, podobnie jak wielu innych pracowników uniwersyteckich, aresztowano i więziono w Ratuszu Poznańskim, następnie umieszczono go w obozie przesiedleńczym przy ul. Głównej w Poznaniu i wreszcie wysiedlono do Generalnej Guberni ${ }^{20}$.

W kontekście intensywnej germanizacji Kraju Warty, w skład którego wchodziła Wielkopolska, naturalne było że podobny los spotkał instytucje prowadzące w Poznaniu poradnictwo psychologiczno-pedagogiczne. W poznańskim Archiwum Państwowym brak materiałów świadczących o ich funkcjonowaniu w okresie okupacji. W literaturze znajdują się odwołania tylko do poradni działających w czasie wojny na terenie Warszawy, z adnotacją, że badacze zajmujący się tym zagadnieniem nie natrafili na informacje dotyczące poradni w innych miastach ${ }^{21}$.

Działania II wojny światowej przerwały dobrze zapowiadający się rozwój poradnictwa psychologiczno-pedagogicznego w Wielkopolsce. Nawet po ich zakończeniu, mimo szybko podjętej odbudowy, jeszcze przez wiele lat nie udało się dojść do poziomu osiągniętego w II Rzeczypospolitej. Wypracowane w okresie międzywojennym koncepcje teoretyczne i praktyczne formy ich realizacji stanowiły jednak punkt odniesienia dla powstających po 1945 r. instytucji poradnictwa.

\footnotetext{
19 Por. J. Topolski, op. cit., s. 300-311; Cz. Brzoza, A. L. Sowa, op. cit., s. 557.

20 Por. Stefan Błachowski, op. cit.

${ }^{21}$ G. Sołtysińska, Oświatowe doradztwo zawodowe dawniej i dziś. Problemy i kierunki działania, „Problemy Poradnictwa Psychologiczno-Pedagogicznego" 1996, nr 2 (5), s. 84.
} 
